\title{
The Role of the International Criminal Judge in the Formation of
}

\section{Customary International Law}

\author{
Noora Arajärvi*
}

\section{$\underline{\text { I. Introduction }}$}

The construction of international customary norms in international criminal law includes a distinctive normative element, and, therefore, in the fields of international law that contain moral considerations, for example the preservation of human life and dignity, the construction of customary law by the courts should not necessarily be limited to the traditional model based on state practice and opinio iuris. Therefore the role of the international criminal judge in evaluating the substance and definition of customary international law is prominent. The main thrust of this paper is to examine whether and how this hypothesis finds support in the case law of the International Criminal Tribunal for the former Yugoslavia (ICTY). Moreover, the approach of the ICTY on the formation of customary international law has not been consistent throughout its operation, and its case law suggests that there have been several periods of varying approaches to the way customary law should be constructed. In the light of these developments in the case law of the ICTY, the changes in custom construction and the reasons for the somewhat capricious approaches of the judges are analysed.

One possible assertion that cannot straightforwardly be excluded is the possibility that the case law of the ICTY points to a new source of international law that is created by the international judge, when the judge bases his analysis in the decision-making on the premise of normative considerations instead of the positivist reality. ${ }^{1}$ However, political considerations in international trials may overshadow the theory that a new source of international law is emerging, because states generally do not wish to move beyond consensual law-making in international relations. Thus, if the judge-made law arising from the international criminal tribunals were considered to be binding, the role of the state as an actor only bound by international law when it so chooses would be diminished.

\footnotetext{
* PhD candidate, European University Institute, Florence (Italy).

${ }^{\mathbf{1}}$ In relation to international judicial decision-making in general, Professor Teson has written that "the commendable purpose [of not having to abandon the positivist illusion], however, should not obscure what is really going on: the adjudication of cases reveals, rather than an interest in finding patterns of state behaviour, an impulse to decide cases correctly by applying the best, just, fair, or efficient rules”; in F.R. TESON, $A$ Philosophy of International Law, Boulder, Westview, 1998, p. 91.
} 
On the other hand, political considerations may underlie the whole rationale of setting up an international criminal tribunal and the scope of jurisdiction granted to it. For instance, the Nuremberg and Tokyo trials have been condemned by a few scholars for being politically motivated and presenting the victor's justice - only the acts committed by the citizens of Nazi Germany and Japan were reviewed, while the conduct of the Allied Powers was left uninvestigated. ${ }^{2}$ Similarly, the ICTY has been criticised for its rejection to review the actions taken by outside entities, such as the North Atlantic Treaty Organisation, during the war in the former Yugoslavia. ${ }^{3}$

In 1988 Georges Abi-Saab stated that:

\begin{abstract}
"We are calling different things custom, we are keeping the name but expanding the phenomenon. After all, custom, if considered from a technical point of view, is not so much the rule; it is procedure of creating the rule. These procedures are changing under our very eyes but we are still calling them custom because of the general recognition of custom as a source capable of creating general international law, while other procedures (or sources) are not or not yet generally recognised or accepted as having this potential. [...] We are no longer speaking of the same source, but we are in the presence of a very new type of law-making”. 4
\end{abstract}

This statement illustrates that the concept of customary international law has not been static even before the inventive methods of custom construction by the international criminal tribunals since the mid-nineties. Nevertheless, the assertion of Abi-Saab is very appropriate in relation to the case law of the ICTY, discussed in more detail in Part II, indeed because the procedure of creating a customary rule has evolved into a quite different form from what was depicted, for example, by Professor D’Amato in 1971. His understanding was that custom consists of strictly limited sources of state practice; in other words, only actual physical acts may constitute state practice for the purpose of the formation of customary rule; and the requirement that practice is preceded or accompanied by articulation that forms the opinio

\footnotetext{
${ }^{2}$ For some references, see G. CLARK, "Yet another example of victor's justice”, The Japan Times, 22 July 2001; for a more detailed discussion on the nature of political trials, see R. CHRISTENSON, “A Political Theory of Political Trials”, Journal of Criminal Law and Criminology, 1983, pp. 547-578, at p. 547.

${ }^{3}$ For critical commentary, see M. MANDEL, How America Gets Away with Murder: Illegal Wars, Collateral Damage and Crimes against Humanity, London, Pluto, 2004; see also V. PESKIN, “Beyond Victor's Justice? The Challenge of Prosecuting the Winners at the International Criminal Tribunals for the Former Yugoslavia and Rwanda”, Journal of Human Rights, 2005, Vol. 4, pp. 213-231, at p. 213.

${ }^{4}$ Comment of GEORGES ABI-SAAB in the discussion on the sources of international law in A. CASSESE and J.H.H. WEILER, Change and Stability in International Law-Making, Florence, European University Institute, 1988, p. 10.
} 
iuris of custom. ${ }^{5}$ However, in some areas of law where the state practice might be scarce or lacking altogether, there is a need for modernised methods of customary law-making in order to respond to the developing needs and interests of the international society. Thus, here the focus is on assessing the construction of custom by international criminal courts, the prospect of judge-made law in the field of international criminal law, and the effects of the changing nature and procedure of custom in international law in general. In the procedure of forming customary rules, here reflecting international criminal law, the judge has become a key-figure in determining the elements that are needed for a custom to emerge, as well as in defining the applicability and definition of a rule of customary international law.

Throughout the article, I shall focus on the case law of the ICTY, making only infrequent references to the other international tribunals, such as the International Criminal Tribunal for Rwanda (ICTR). This is for the reason that the interpretation of customary international law has been the most recurring in the cases of the ICTY, primarily because only the ICTY has been required by its Statute to apply only law that is "beyond any doubt part of customary law”.

\section{Genesis of international customary criminal law as reflected in international} judicial decisions

\section{$\underline{\text { A. Traditional sources of customary international law and international criminal }}$} $\underline{\text { law }}$

The 1945 Statute of the International Court of Justice ${ }^{6}$ reproduces the list of sources of international law as codified in the Statute of the Permanent Court of Justice in the $1920,{ }^{7}$ and it defines international custom as evidence of a general practice accepted as law. The method of custom construction that is often seen to derive from Article 38 of the Statute is here referred to as the traditional model, consisting of two elements, state practice and opinio iuris. One of the earliest precedents where the terminology of the traditional model was articulated was in the case Paquete Habana by the United States Supreme Court in $1900 .^{8}$ The court held that fishing vessels were exempt from capture as prizes of war under a rule of customary

\footnotetext{
${ }^{5}$ A. D’AMATO, The Concept of Custom in International Law, Ithaca, Cornell University Press, 1971.

${ }^{6}$ Statute of the International Court of Justice, 16 June 1945.

${ }^{7}$ Statute of the Permanent Court of Justice, 16 Dec. 1920.

${ }^{8}$ United States Supreme Court, Paquete Habana Case, 8 Jan. 1900, 175 US, 677, at p. 700.
} 
international law, evidenced by earlier treaties, national orders and instruction of many states and works of jurists and scholars. The two elements of the traditional model, state practice and opinio iuris, were further elaborated in the subsequent cases, in 1927 by the Permanent Court of International Justice in the Lotus Case, ${ }^{\mathbf{9}}$ and in 1950 by the International Court of Justice (ICJ) in the Asylum Case. ${ }^{\mathbf{1 0}}$

The traditional model has been interpreted in various ways by courts as well as by scholars. For example, Frederick Kirgis’s sliding scale theory from 1987 introduces the idea of the relative significance or weight of the state practice and opinio iuris. The theory is based on the idea that "the more destabilising or morally distasteful the activity [...] the more readily international decision makers will substitute one element for the other, provided that the asserted restrictive rule seems reasonable."11 I mention the sliding scale theory here as an example of one interpretation given to the traditional conception of custom as a summation of the state practice and opinio iuris, because it contains connotations similar to that of custom construction by the international criminal tribunals. Moreover, the discretion on determining what consists of "destabilising or morally distasteful activity”, and thus the relative weight given to practice and opinio iuris is left to the "international decision maker"; in other words, the judge. For example, the ICTY has concluded in relation to the principles of humanitarian law that these principles can materialise as customary norms even if the state practice is scarce or nonexistent, but "the demands of humanity or the dictates of public conscience" stress the need for such a customary norm. ${ }^{12}$

In the North Sea Continental Shelf Case, ${ }^{13}$ the ICJ relied largely on the actual state practice; whereas, in the Nicaragua Case, ${ }^{\mathbf{1 4}}$ the actual practice was not even thoroughly examined, and instead the court gave priority to words over deeds, emphasising the importance of opinio iuris in international custom formation. It could be said that in the latter case the ICJ considered the underlying issue of international peace and security so important,

\footnotetext{
${ }^{9}$ I.C.J., Lotus Case [France v. Turkey], 7 Sept. 1927, 4 ILR, 153.

${ }^{10}$ I.C.J., Asylum Case [Colombia/Peru], 20 Nov. 1950; for commentary, see H.W. BRIGGS, “The ColumbianPeruvian Asylum Case and Proof of Customary International Law”, American Journal of International Law, 1951, pp. 728-731, at p. 728.

${ }^{11}$ F.L. KIRGIS, “Custom on a Sliding Scale”, American Journal of International Law, 1987, pp. 146-151, at p. 149.

${ }^{12}$ I.C.T.Y., Prosecutor v. Kupreskic, IT-95-16-T, Judgment, 14 Jan. 2000, § 527.

${ }^{13}$ I.C.J., North Sea Continental Shelf Cases [Federal Republic of Germany/Denmark; Federal Republic of Germany/Netherlands], 20 Feb. 1969.

${ }^{14}$ I.C.J., Military and Paramilitary Activities in and against Nicaragua [Nicaragua v. The United States], 27 June 1986.
} 
whether on practical or moral grounds, that to deny a customary rule prohibiting the use of force and intervention in the affairs of sovereign states would reduce the significance of international law, as well as reduce confidence in the court. ${ }^{15}$

In international criminal courts similar rationales, international peace and security, protection of fundamental human rights, preservation of life and so on, could explain the need to move away from traditional model of custom construction. In the next Part of this paper, I concentrate my analysis on a limited number of cases, mainly from the ICTY, and discuss the methods of constructing customary norms used in those cases and if, and how, these methods differ from the traditional model. First, however, it is essential to go back in history to the Nuremberg tribunal after the Second World War, because this was the first instance where customary international norms relating to international criminal law were articulated.

\section{B. Nuremberg military tribunal}

The Nuremberg Trial of the Major War Criminals (IMT) was the first occasion where international criminal law was applied directly by an international tribunal. ${ }^{16}$ It was not entirely unprecedented, however because judicial proceedings on war crimes had long existed, just as war crimes and aggression had been present much before the mid-twentieth century. In the words of Georg Schwarzenberger, "unfortunately, the history of international relations prior to 1939 does not easily lend itself to description in terms of an international Garden of Eden in which the original sin has still to be committed". ${ }^{17}$ Nonetheless, the establishment of the Nuremberg tribunal was at the time considered to be the focal point in crystallising the individual criminal responsibility for international crimes as well as defining the scope of those crimes.

Before and at the time of the proceedings of the IMT and the International Military Tribunal for the Far East in Tokyo the treaties on international criminal were scarce. Especially the crimes against humanity had not been codified, and no precedents of tribunals

\footnotetext{
${ }^{15}$ H.C.M. CHARLESWORTH, “Customary International Law and the Nicaragua Case”, Australian Yearbook of International Law, 1984-1987, pp. 1-30, at pp. 27-29.

${ }^{16}$ IMT was set up by Agreement for the Prosecution and Punishment of the Major War Criminals of the European Axis, and the Charter of the International Military Tribunal, 8 Aug. 1945, London, 82 UNTS, 280.

${ }^{17}$ G. SCHWARZENBERGER, “The Judgment of Nuremberg”, Tulane Law Review, 1947, pp. 329-361, at pp. 338-339.
} 
invoking the crimes against humanity existed. Hence the tribunal had to find other sources of law on which to base its jurisdiction. One interpretation was that the Charter of the Military Tribunal codified pre-existing norms, either those under international custom or general principles of law. In the same vein, it has been put forth that the norms pronounced in the Charter stem from the natural law and are therefore higher principles of morality, and thus they do not violate the principles of legality. ${ }^{\mathbf{1 8}}$ Judith Shklar has completely rejected any role of natural law in the Nuremberg trials. She writes: "natural law thinking played no part in Nuremberg, where every effort was made to build on the fiction of positive international law envisaged as analogous in its formal structure to the legalistic image of municipal law in matured systems”. ${ }^{19}$ The problematic relation between the application of international criminal law and the principles of legality is further discussed in Part III of this paper.

Whether or not one agrees with Shklar on the absence of the natural law basis of the jurisdiction, it is useful to examine briefly, before turning into an analysis of the construction of custom by the ICTY, what sources the Nuremberg tribunal invoked in instituting the international criminality of certain acts and more precisely for this study, the sources of customary international law.

\section{Customary status of Nuremberg crimes}

In relation to war crimes, the Nuremberg tribunal bluntly accepted that the 1907 Hague Convention IV Respecting the Laws and Customs of War on Land ${ }^{\mathbf{2 0}}$ was without a doubt declaratory of existing customary international law and could be directly applied in the proceedings. $^{21}$

In considering the crimes against peace, the tribunal held that prohibition to wage aggressive war had developed into a customary norm that had been codified in the 1928 Pact of Paris (also known as the Kellogg-Briand Pact). ${ }^{22}$ Subsequently, some scholars have argued

\footnotetext{
${ }^{18}$ See, for example, S. GARIBIAN (translated from French by G. M. GOSHGARIAN), “Crimes Against Humanity and International Legality in Legal Theory after Nuremberg”, Journal of Genocide Research, 2007, pp. 93-111.

19 J.N. SHKLAR, Legalism: Law, Morals, and Political Trials, Cambridge (Mass.), Harvard University Press, 1964, at p. 156.

${ }^{20}$ Hague Convention IV Respecting the Laws and Customs of War on Land, 18 Oct. 1907, 1 Bevans 631.

${ }^{21}$ I.M.T., Nuremberg Judgment, 1946, Cmd. 6964, at p. 64.

${ }^{22}$ General Treaty for the Renunciation of War as an Instrument of National Policy, 27 Aug. 1928, 94 LNTS. 57.
} 
that the prohibition to wage aggressive war had undoubtedly been proscribed by the norms of natural law, and that the Pact of Paris brought this prohibition into the sphere of positive international law, thus being positivised natural law. ${ }^{23}$ Although the tribunal considered it unnecessary to define "whether and to what extent, aggressive war was a crime before the execution of the London Agreement”, ${ }^{24}$ it still drew attention to a few instruments dealing with violations of peace. With the exception of the 1907 Hague Convention IV, ${ }^{25}$ the instruments discussed were not legally binding, and the decision to cite them as evidence of the emerged customary rule has later been criticised, for example by Schwarzenberger, for not providing, at the time, a sound basis for establishing either state practice or, moreover, opinio iuris. $^{26}$

Schwarzenberger points to the fact that the actual practice of states before and during the Second World War goes against the findings of the tribunal that the prohibition to wage aggressive war had come to exist under customary law. Various examples, including the invasion of Manchuria by the Soviet Union (1929) and subsequently by Japan (1931), Italy's occupation of Albania (1939) and the preventive war by the Soviet Union against Finland (1939), confirm that states on various continents had been engaging in actions identical to that which the court announced to amount to a crime against peace. ${ }^{27}$

IMT linked the crimes against humanity to war crimes and to the crime of aggression, and thus brought it them under the scope of customary international law, by simply stating, without further elaboration, that "in so far as the inhumane acts charged in the Indictment, and committed after the beginning of the war, did not constitute war crimes, they were all committed in execution of, or in connection with, the aggressive war, and therefore constituted crimes against humanity”. ${ }^{28}$ IMT, probably intentionally, omitted entering into any

\footnotetext{
${ }^{23}$ See, for example, Q. WRIGHT, “War Crimes under International Law”, Law Quarterly Review, 1946, pp. 4052; for more general discussion, see Q. WRIGHT, “The Law of the Nuremberg Trial”, American Journal of International Law, 1947, pp. 38-72.

${ }^{24}$ I.M.T., Nuremberg Judgment, 1946, Cmd. 6964, at p. 38.

${ }^{25}$ The judgment refers to the 1923 Draft Treaty of Mutual Assistance, 1924 Geneva Protocol and 1927 Resolution of the Assembly of the League of Nations.

${ }^{26}$ G. SCHWARZENBERGER, “The Judgment of Nuremberg”, at pp. 345-347.

${ }^{27}$ Ibid., at pp. 347-348.

${ }^{28}$ I.M.T., Nuremberg Judgment, at p. 249. In the later case law, it has been held that it is not necessary to establish a link between crimes against and war crimes or crime of aggression: "it is by now a settled rule of customary international law that crimes against humanity do not require a connection to international armed conflict [or] any conflict at all”; ICTY, Appeals Chamber, Prosecutor v. Tadic, IT-94-1-AR72, Decision on the Defence Motion for Interlocutory Appeal on Jurisdiction, 2 Oct. 1995, § 141.
} 
discussion on whether crimes against humanity were a new category of offences and hence $e x$ post facto law.

Some of the official declarations made by the Allied Nations during the Second World War condemning the acts of the Nazis were invoked in the Nuremberg trial as evidence of state practice that a customary norm prohibiting the crimes against peace, war crimes and crimes against humanity had emerged. In addition to the Charter of the International Military Tribunal, as an instrument confirming and codifying pre-existing norms of customary international law as well as the tribunal's interpretation of the customary law, the United Nations General Assembly passed two resolutions in 1946 that affirmed the principles of law articulated by the Nuremberg tribunal. ${ }^{29}$ These resolutions have been relied on in subsequent cases as further confirming the customary nature of the Nuremberg law. ${ }^{\mathbf{3 0}}$

If one compares the right of the accused to challenge the legality of the proceedings under customary international law in the Nuremberg tribunal and in the subsequent ad hoc criminal tribunals, there is a definite development, much of which has been induced by the emergence of human rights law that endorses the right to a fair and uncontentious trial. ${ }^{31}$ For instance, in Nuremberg, according to Article 3 of the Charter of the International Military Tribunal, the accused did not have the right to challenge the legality of the tribunal or its judges, and this restriction was considered to comply with the minimum requirements of a fair trial. Oppositely, in the Tadic Case (1995) the ICTY was challenged by the accused asserting that the ICTY was not established legally, it had wrongful primacy over the jurisdiction of the national court, and it lacked jurisdiction ratione materiae..$^{32}$ In relation to the challenge of the primacy of the ICTY over national courts, the Trial Chamber held that only a sovereign state could invoke such an argument, and an individual, as in Tadic, was not entitled to raise the issue. $^{33}$ The Appeals Chamber argued against the reasoning of the Trial Chamber. It stated

\footnotetext{
${ }^{29}$ Resolution 3(I) on Extradition and Punishment of War Criminals, 13 Feb. 1946; Resolution 95(I) on Affirmation of the Principles of International Law recognised by the Charter of the Nuremberg Tribunal, 11 Dec. 1946.

${ }^{30}$ For example, House of Lords, $R$. v. Bow Street Metropolitan Stipendiary Magistrate and Others (Ex parte Pinochet Ugarte), 25 Nov. 1998, [2000] 1 AC 61; E.C.H.R., Kolk and Kislyiy v. Estonia [Non-Applicability of Statutory Limitations to Crimes against Humanity], 17 Jan. 2006.

${ }^{31}$ For example, see 1950 European Convention on Human Rights, Article 6; 1966 International Covenant on Civil and Political Rights, Article 14.

${ }^{32}$ I.C.T.Y., Appeals Chamber, Prosecutor v. Tadic, IT-94-1-AR72, Decision on the Defence Motion for Interlocutory Appeal on Jurisdiction, 2 Oct. 1995.

33 "A plea that the sovereignty of a state has been violated, a plea only a sovereign state may raise or waive and a right clearly the accused cannot take over from that state”; Ibid. at §§ 41-42.
} 
that international law has moved away from state-centralism to a more human-centred approach, and an individual was allowed to raise the issue of primacy. However, the Appeals Chamber did not accept the challenge to primacy dismissing it on the ground that "the offences which, if proven, do not affect the interests of one state alone but shock the conscience of mankind”. ${ }^{34}$

On the other hand, the ICTY has wider jurisdictional basis than the Nuremberg tribunal, despite the notion that it must apply humanitarian law that is beyond doubt customary international law, while it was held in the Nuremberg Judgment that "the freedom of the Tribunal to apply international customary law is limited by its overriding duty to apply the law of its Charter whether or not such law is declaratory of existing international law". 35 This judgment means that in Nuremberg trials the Charter of the International Military Tribunal, in which some customary international norms were codified, was considered to be the exclusive source of applicable law, providing an exhaustive list of crimes falling under its jurisdiction. Conversely, the Statute of the ICTY provides the tribunal with wider discretion to determine the substantive scope of its jurisdiction. For instance, Article 3 list crimes that are violations of the laws or customs of war, but adds that the violations are not limited to the list; and, in Article 5 on crimes against humanity, the last provision of a similar list states that the court has power to prosecute individuals for also “other inhumane acts”.

III. International criminal ad hoc tribunals and role of the judge in the formation of customary law

\section{A. Establishment of the ICTY, the ICTR and their jurisdiction}

Unlike with the pre-existing dispute settlement bodies, such as the International Court of Justice, the establishment of the International Criminal Tribunal for the former Yugoslavia and the International Criminal Tribunal for Rwanda was not based on the consent of equal states but was a unilateral, 'peremptory' decision by the executive body of an international organisation, thus the setting up of the tribunals illustrated the will of the most powerful states.

\footnotetext{
${ }^{34}$ Ibid, § 57. For further commentary, see A. BIRDSALL, "The International Criminal Tribunal for the former Yugoslavia: Towards a More Just Order?”, Peace Conflict \& Development, 2006, wWw.peacestudiesjournal.org.uk.

${ }^{35}$ I.M.T., Nuremberg Judgment, 1946, Cmd. 6964, at p. 109.
} 
In 1993, after a number of resolutions condemning the violations of international humanitarian law in the territory of the former Yugoslavia, the Security Council decided by the Resolution 808 to set up International Criminal Tribunal for the former Yugoslavia to deal with the atrocities committed after 1991 in that territory. ${ }^{36}$ The following year the Security Council created the International Criminal Tribunal for Rwanda. ${ }^{37}$ The resolutions were adopted under the powers granted to the Security Council by the Chapter VII of the Charter of the United Nations, and thus the situations were determined to be threats to international peace and security.

In initiating the establishment of the ICTY by the Resolution 808, the Security Council requested the Secretary-General to submit a report on all aspects, for example the legal basis and the subject-matter jurisdiction, relating to the establishment of the ICTY. The Report of the Secretary-General Pursuant to Paragraph 2 of the Security Council Resolution 808 (1993) sets out a Statute for the ICTY ${ }^{\mathbf{3 8}}$ with explanations of each article. ${ }^{\mathbf{3 9}}$ The tribunal has the competence to apply international humanitarian law that is "beyond any doubt part of customary law so that the problem of adherence of some but not all states to specific conventions does not arise". ${ }^{40}$ Also, by resorting to the norms that are beyond any doubt customary international law, the court complies with the nullum crimen sine lege principle, which I will address in more detail in Part III of this paper.

Among the sources of law applicable by the ICTY, the Report of the SecretaryGeneral lists international legal instruments that are also part of customary law relating to armed conflict: the 1949 Geneva Conventions, the 1907 Hague Convention IV Respecting the Laws and Customs of War on Land (as also discussed in Nuremberg) and the Regulations annexed to it, the 1948 Convention on the Prevention and Punishment of the Crime of Genocide, and the 1945 Charter of the International Military Tribunal. Interestingly, the nature of the armed conflict -international or internal- is not mentioned in relation to the competencies of the tribunal's. This omission is most likely a deliberate one, made in order to avoid raising the question whether, and at what point in time, the conflict in the territory of the

\footnotetext{
${ }^{36}$ United Nations Security Council Resolution 808, 25 May 1993, UN Doc. S/25704.

${ }^{37}$ United Nations Security Council Resolution 955, 8 Nov. 1994, UN Doc. S/RES/955.

${ }^{38}$ Statute of the International Tribunal for the Prosecution of Persons Responsible for Serious Violations of International Humanitarian Law Committed in the Territory of the Former Yugoslavia since 1991, 25 May 1993, UN SC Res. 827, 32 I.L.M. 1203 (1993).

${ }^{39}$ Report of the Secretary-General Pursuant to Paragraph 2 of the Security Council Resolution 808, 3 May 1993, available at http://www.un.org/icty/legaldoc-e/index.htm.

${ }^{40}$ Ibid., § 34 .
} 
former Yugoslavia constituted an internal as opposed to an international conflict, and thus when the existence of the state of Yugoslavia ended and was succeeded by six of the former Yugoslav republics. The status of successor states in relation to the treaties signed by the predecessor has not been ultimately clarified in international law, but it is the prevailing view, with some exceptions to the new decolonised states, that all states are bound by customary international norms. ${ }^{41}$ By applying only those norms that have become part of customary international law at the time the alleged atrocities took place, the court, again, would act in conformity with the nullum crimen principle. However, in its case law, the ICTY has engaged in a discussion on the differences of the customary international norms applicable to international and internal armed conflicts and has stated that the international humanitarian law governs the conduct in both international and internal armed conflicts. More precisely, by scrutinising the intention of the Security Council in creating the Statute of the ICTY, and by employing logical and systematic methods of interpretation, the court has concluded that it has jurisdiction regardless of whether the acts took place during an internal or an international armed conflict. $^{42}$

The International Criminal Tribunal for Rwanda was created by the Security Council Resolution 955 (1994). ${ }^{43}$ The ICTR Appeal Chamber stated, in the Rutaganda Case, that:

\footnotetext{
"The creation of the Tribunal, in response to the alleged crimes perpetrated in Rwanda in 1994, raised the question all too familiar to the Nuremberg Tribunal and the ICTY, that of jurisdictions applying ex post facto laws in violation of this principle [of prohibition of ex post facto laws]. In establishing the ICTY, the Secretary-General dealt with this issue by asserting that in the application of the principle of nullum crimen sine lege the International Tribunal should apply rules of international humanitarian law, which are beyond any doubt part of customary law. However, in the case of this Tribunal, i.e. the ICTR, it was incumbent on the Chambers to decide whether or not the said principle had been adhered to, and whether individuals incurred individual criminal responsibility for violations of these international instruments". 44
}

\footnotetext{
${ }^{41}$ For further elaboration, see for example P. MALANCZUK, Akehurst's Modern Introduction to International Law, 7th ed., London, Routledge, 1997, at pp. 47 (state succession and customary international law) and 161-172 (general description of state succession in international law).

42 For instance: Tadic, supra note 32, § 137.

${ }^{43}$ Statute of the International Criminal Tribunal for the Prosecution of Persons Responsible for Genocide and Other Serious Violations of International Humanitarian Law Committed in the Territory of Rwanda and Rwandan citizens responsible for genocide and other such violations committed in the territory of neighboring states, between 1 January 1994 and 31 December 1994, 8 Nov. 1994, UN SC Res. 955, 33 ILM 1598.

${ }^{44}$ I.C.T.R., Prosecutor v. Rutaganda, ICTR-96-3, 6 Dec. 1999, § 86.
} 
At the time when the acts considered by the ICTR took place, in 1994, Rwanda was a party to the Geneva Conventions, ${ }^{45}$ both Additional Protocols thereto, ${ }^{46}$ as well as the Genocide Convention, ${ }^{47}$ and therefore those legal instruments could be applied directly by the court, without having to show that the norms codified in the instruments had acquired the status of customary international law.

\section{B. Construction of customary international law by the ICTY}

The Appeals Chamber of the ICTY held in the Tadic Case (1995) that the common Article 3 of the 1948 Geneva Conventions reflects customary international law. ${ }^{48}$ In analysing the customary nature of the Article 3 encompassing rules protecting civilians in a noninternational armed conflict, the court in Tadic said that finding evidence of actual state practice is difficult because in situations of non-international conflicts independent observers are most often not allowed to inspect the behaviour of the parties to the conflict in the battlefield. Instead, the court observed that "reliance must primarily be placed on such elements as official pronouncements of states, military manuals and judicial decisions" ${ }^{49}$ The court went on to point to various sources in reviewing the evidence of state practice and opinio iuris relating to the protection of civilians in civil war, starting from the declarations made during the Spanish Civil War. Confirmation of the principles on the protection of civilians set out in the declarations was found in the resolutions of the Assembly of the League of Nations. Interestingly, as a further evidence of state practice on the protection of civilians in the non-international conflicts, the court referred to Mao Tse-Tung's 1961 Manifesto of the Chinese People's Liberation Army. Also the minimum conditions of the common Article 3 of the Geneva Conventions were invoked as an evidence of the customary

\footnotetext{
451949 Geneva Convention for the Amelioration of the Condition of the Wounded and Sick in the Field, 75 UNTS, 31; 1949 Geneva Convention for the Amelioration of the Condition of Wounded, Sick and Shipwrecked Members of Armed Forces at Sea, 75 UNTS, 85; 1949 Geneva Convention Relative to the Treatment of Prisoners of War, 75 UNTS, 13; 1949 Geneva Convention Relative to the Protection of Civilian Persons in Time of War, 75 UNTS, 267; all adopted on 12 Aug. 1949.

${ }^{46} 1977$ Protocol Additional to the Geneva Conventions of 12 August 1949, and relating to the Protection of Victims of International Armed Conflicts; 1977 Protocol Additional to the Geneva Conventions of 12 August 1949, and Relating to the Protection of Victims of Non-International Armed Conflicts, 16 ILM 1391 and 1442; both adopted on 8 June 1977.

${ }^{47}$ Convention on the Prevention and Punishment of the Crime of Genocide, 9 Dec. 1948, 78 UNTS, 277.

48 Tadic, supra note 32, § 99.

49 Ibid.
} 
nature of the protection of civilians, as confirmed by the ICJ in the Nicaragua Case and expressed by the subsequent state practice. ${ }^{\mathbf{5 0}}$

In addition, the Tadic court stated that the results of the work of the International Committee of the Red Cross (ICRC) are "an element of actual international practice, this is an element that has been conspicuously instrumental in the emergence or crystallisation of customary rules". ${ }^{\mathbf{1 1}}$ However, the court did not discuss whether the reports or the practical functions carried out by the ICRC affect the formation of customary norms as such, or whether the reports and the function are relevant merely through their influence on the states. Nonetheless, by referring to the ICRC that is a non-governmental organisation the court paves the way for custom formation beyond state-dominated law creation. Furthermore, the court explicitly includes international practice as a relevant source of customary law, and if the international practice is understood as acts of international organs (that perhaps can be said to have international personality) instead of merely an expression used to describe that many states act in a same way on an international sphere, it is, yet again, a development away from the state-domination of international law.

Moreover, two Resolutions of the United Nations General Assembly were cited in Tadic Case as declaratory of existing principles of customary international law: Respect of Human Rights in Armed Conflict (1968) and Basic Principles for the Protection of Civilian Populations in Armed Conflicts (1970). ${ }^{52}$ Both resolutions were adopted unanimously and served also the function of promoting the adoption of treaties and clarifying the existing principles of the protection of civilians in the armed conflicts. ${ }^{53}$

The Tadic court also referred to the statements made by groups of states, either in intergovernmental or in supranational contexts. For example, in 1990 the European Community and its member states drew up a declaration regarding the situation in Liberia, and in 1995 the European Union issued a declaration on the situation in Chechnya. In addition to these statements of the European Community and subsequently the European Union, many resolutions of the Security Council of the Nations, both general and country-specific, were

\footnotetext{
${ }^{50}$ References are made to the 1967 conflict in Yemen, the statement of the Prime Minister of Congo in 1964 during the civil war in Congo, the 1967 Operational Code of Conduct for Nigerian Armed Forces and the 1988 statement by the rebels in El Salvador; Tadic, supra note 32, §§ 105-107.

${ }^{51}$ Ibid., § 109.

${ }^{52}$ United Nations General Assembly Resolutions 2444 and 2675 (respectively).

${ }^{53}$ Tadic, supra note 32, § 112.
} 
considered by the court as articulations of general principles and norms on the protection of the civilians in non-international armed conflicts. ${ }^{54}$ The court concluded that, even though the declarations and resolutions did not explicitly refer to the common Article 3 of the Geneva Conventions, they included the standards set out in the common Article 3 and, moreover, went beyond its scope in the protection of civilians in non-international armed conflicts. The latter aspect is supportive of the willingness of the court to find customary rules aiming for a broader protection of human beings, and it illustrates that the court does not necessarily rely on the scope of treaties when establishing that a customary norm has emerged.

In relation to the 1949 Second Additional Protocol to the Geneva Conventions ${ }^{55}$ applicable to conflicts of non-international character the court acknowledged that "many provisions of this Protocol can now be regarded as declaratory of existing rules or as having crystallised in emerging rules of customary law or else as having been strongly instrumental in their evolution as general principles”. ${ }^{56}$ In determining the customary status of some of the provisions of the Second Additional Protocol, the Tadic court relied on "the views expressed by a number of states” and the principles found in military manuals. Unfortunately, the analysis of both was sparse, with limited examples of the views of states or texts of military manuals, reference being made only to the 1987 situation of El Salvador and 1992 German Military Manual. Unlike in some cases of the ICTY that followed after Tadic, the court did not avoid using the traditional vocabulary of custom formation, but used the traditional expressions "state practice” and “opinio iuris”.

In many points of the case Furundzija (1998) the Trial Chamber of the ICTY examined whether customary rules prohibiting various alleged offences exist that give rise to individual criminal responsibility. ${ }^{57}$ The methods in reaching conclusions varied from point to point. In relation to torture as a war crime the court stated that the "general prohibition against torture has evolved in customary international law". ${ }^{58}$ In analysing the evolution of this prohibition, the court refrained from entering into traditional custom formation discourse of finding evidence of state practice and opinio iuris. Instead, it looked into written documents on the prohibition of torture as a war crime in order to establish if the provisions had evolved

\footnotetext{
${ }^{54}$ Ibid., § 16.

551977 Additional Protocol II, supra note 46.

${ }^{56}$ Tadic, supra note 32, § 117.

${ }^{57}$ I.C.T.Y., Prosecutor v. Furundzija, IT-95-17/1-T, Judgment, 10 Dec. 1998.

${ }^{58}$ Ibid., § 137.
} 
into customary law. The documents cited as evidence that a general prohibition of torture exists under customary law include the 1863 Lieber Code, the 1907 Hague Conventions together with the so-called Martens clause in the preamble of the 1899 Second Hague Convention, and the 1946 Allied Control Council Law No 10 which incorporated torture into the list of crimes against humanity.

Geneva Conventions and the fact that they have virtually universal ratification were invoked as the main source of evidence of the customary nature of torture as a war crime. ${ }^{\mathbf{5 9}}$ The Furundzija court also stated that the content of the prohibition of torture is the same under customary international law and under the treaty law, a issue discussed in more detail in Part III B. Even though the court did not use the traditional vocabulary in establishing custom, it did resort to practice and declarations of states in concluding that no state has officially authorised the use of torture in armed conflict, and in facing allegations of torture states have either denied the existence of such practice or condemned it as a unique error of an individual official. By behaving in this manner, the states have not downgraded the prohibition of torture but have accepted the normative prohibition even when actual positive practice may not affirm it.

As the last point, the court referred to the Nicaragua Case $^{\mathbf{6 0}}$ of the ICJ, a case that did not concern torture but the formation of custom in international law in general. ${ }^{\mathbf{6 1}}$ However, the ICJ had stated that the common Article 3 of the Geneva Conventions, which explicitly mentions also torture, ${ }^{62}$ had developed into customary international law. ${ }^{63}$

In order for individual criminal responsibility to arise there must exist a definition of the elements of the crime. The court in Furundzija began this analysis of the definition of the elements of torture by stating that international humanitarian law does not offer such definition. ${ }^{64}$ The definition drawn from the Torture Convention ${ }^{65}$ had been applied by the

\footnotetext{
${ }^{59}$ Ibid., § 138; in the previous paragraph the court referred in passing to a decision of the Constitutional Court of Columbia which had held that the Geneva Conventions and also the Additional Protocols thereto have in their entirety become customary law.

${ }^{60}$ Nicaragua, supra note 14.

${ }^{61}$ Furundzija, supra note 57, § 138.

62 Geneva Conventions, Article $3 \S 1$ (a).

${ }^{63}$ For discussion, see T. MERON, "The Geneva Conventions as Customary Law”, American Journal of International Law, 1987, pp. 348-370.

${ }^{64}$ Furundzija, supra note 57, § 159.

${ }^{65}$ Convention against Torture and Other Cruel, Inhuman or Degrading Treatment or Punishment, 10 Dec. 1984, U.N. Doc. A/39/51, 1465 UNTS, 85.
} 
ICTR in the Akayesu Case ${ }^{\mathbf{6 6}}$ but the ICTY considered that unless it can show that the definition has crystallised in customary criminal law, in other words as a customary norm giving rise to individual criminal responsibility instead of state responsibility which the Torture Convention imposes, it cannot apply that definition in criminal cases under its jurisdiction. The Furundzija court drew its reasoning from a previous decision of the ICTY, Delalic (1998). ${ }^{67}$ In looking for a definition torture, the Trial Chamber in Delalic discussed various legal instruments, and in relation to the Inter-American Convention to Prevent and Punish Torture ${ }^{68}$ it stated that "the definition of torture contained in Article 2 thereof (the Inter-American Convention) incorporates, but is arguably broader than, that contained in the Torture Convention”. ${ }^{69}$ However, the Furundzija court in referring and agreeing with Delalic said that "Trial Chamber II of the International Tribunal has rightly noted in Delalic that indeed the definition of torture contained in the 1984 Torture Convention is broader than, and includes, that laid down in the 1975 Declaration of the United Nations General Assembly and in the 1985 Inter-American Convention”. ${ }^{70}$ According to my reading of the cases the Furundzija court has misread Delalic. As noted above, in Delalic the definition in the InterAmerican Convention is said to be broader than the one in Torture Convention, whereas Furundzija court had understood Delalic’s position oppositely.

In investigating whether a definition of torture has become to exist in customary law and what the contents of that definition would be, the Furundzija court held that although the definition of the Torture Convention is limited to the scope of that Convention it can still be an authoritative source "because it spells out all the necessary elements implicit in international rules on the matter". ${ }^{71}$ The court thus considered that it could be utilised as part of the evidence of the emergence of a customary definition for torture. Further evidence spelling out similar or coinciding definitions was drawn from the United Nations Declaration on Torture, ${ }^{72}$ which had been adopted in the General Assembly by consensus. In addition, the court pointed to the definitions set forth in the Inter-American Convention to Prevent and Punish Torture and by the United Nations Special Rapporteur, European Court of Human

\footnotetext{
${ }^{66}$ I.C.T.R., Prosecutor v. Akayesu, ICTR-96-4-T, Judgment, 2 Sept. 1998.

${ }^{67}$ I.C.T.Y., Prosecutor v. Delalic and Others, IT-96-21-T, Judgment, 16 Nov. 1998.

${ }^{68}$ Inter-American Convention to Prevent and Punish Torture, 9 Dec. 1985, OAS Treaty Series No 67, 25 ILM, 519.

${ }^{69}$ Delalic, supra note 67, § 458.

${ }^{70}$ Furundzija, supra note 57, § 160.

${ }^{71}$ Ibid.

${ }^{72}$ Declaration on the Protection of All Persons from Being Subjected to Torture and Other Cruel, Inhuman or Degrading Treatment or Punishment, 9 Dec. 1975, UN GA Res. 3452, UN Doc. A/10034.
} 
Rights, and the Human Rights Committee of the United Nations. ${ }^{73}$ The court then concluded that "the broad convergence of the aforementioned international instruments and international jurisprudence demonstrates that there is now general acceptance of the main elements contained in the definition set out in the Article 1 of the Torture Convention”, ${ }^{74}$

The Furundzija court can be said to have had an impact on the method of formation of customary international law by creating judge-made custom. However, Furundzija is not an unprecedented example of a judge-made custom. Without going into the merits of the case, in the North Sea Continental Shelf case (1969) the ICJ implied that the formation of custom could be said to arise not from explicit external facts but from the judge. ${ }^{75}$ After the ICJ announced its decision, Wolfgang Friedmann wrote that in the North Sea Continental Shelf Case the decision of the court was ex aequo et bono ('according to what is right and good') under the disguise of interpretation. ${ }^{76}$ Thus, the court did not interpret law as it stood but in manner that it considered would lead to the most just outcome for the parties to the dispute. ${ }^{77}$ In his article Friedmann acknowledged the same dilemma that is still deliberated with regard to the case law of the ICTY: the focal problem of the international courts is that "the borderlines between interpretation of existing law and the making of new law are inevitably fluid". 78

The case Krstic concerned the criminal responsibility of General Krstic for acts, including mass executions and forcible transfer of Bosnian Muslims, which took place in Srebrenica in $1995 .{ }^{79}$ In relation to the killings the accused was charged with genocide, and alternatively, with complicity to genocide. The Trial Chamber considered that the definition given to the crime of genocide in Article $4 \S 2$ of the Statute of the ICTY needs to be

\footnotetext{
${ }^{73}$ Furundzija, supra note 57, § 160.

${ }^{74}$ Ibid. § 161.

${ }^{75}$ I.C.J., North Sea Continental Shelf Cases, supra note 13.

${ }^{76}$ W. FRIEDMANN, “The North Sea Continental Shelf Cases: A Critique”, American Journal of International Law, 1970, pp. 229-240, at p. 236.

${ }^{77}$ Eyal Benvenisti has presented a theory of custom formation based on efficiency. He has suggested that in the Gabcikovo-Nagymaros Project Case the ICJ bypassed the traditional construction of customary norms in relation to environmental issues. Benvenisti considers that "the ICJ has [...] the power to invent custom" if the newly formed custom is more efficient, no other entity is taking active steps towards the same goal, and treaties (or treaty negotiations) between states have been inefficient, usually because of the non-reciprocal nature of the issues at hand in the custom formation. Despite the disputable nature of this interpretation, perhaps something from the efficiency argument could be incorporated into the construction of custom by international criminal tribunals. This, however, so far has not been really at the focus of my research, but it is an initiative to be kept in mind while analysing the construction of customary norms by the international criminal courts.

${ }^{78}$ W. FRIEDMANN, “The North Sea Continental Shelf Cases”, o.c., at p. 235.

${ }^{79}$ I.C.T.Y., Prosecutor v. Krstic, IT-98-33-T, Judgement, 2 Aug. 2001.
} 
interpreted taking into account the customary international law at the time the act was committed. The court, again, did not resort to finding evidence of state practice and opinio iuris but, instead, referred to five different sources arising mainly from the international sphere.

First, the court stated that the Genocide Convention was the main source because Article 4 of the ICTY Statute adopts its definitions. In addition, the Genocide Convention has been acknowledged to have codified existing norms of international law, as was affirmed in the advisory opinion of the ICJ in Reservations to the Convention on the Prevention and Punishment of Genocide (1951). ${ }^{\mathbf{8 0}}$

Secondly, the court considered international case law, especially in the ICTR, as a source of customary law. For instance, in discussing the meaning of a 'group' as a target of genocide, the court recognised that in the cases Akayesu (1998) and Kayishema and Ruzindana (2001) the ICTR confirmed the principles put forth in preceding soft law instruments such as the UN General Assembly resolution 96 (1946), the statement of the UN Secretariat (1948), the ICJ judgment in the case in Reservations to the Convention on the Prevention and Punishment of Genocide (1951), and finally by the International Law Commission (1996).

Thirdly, the reports of international committees, for instance the Report of the International Law Commission on the Draft Code of Crimes against Peace and Security of Mankind, were stated to be relevant for the interpretation of the Article 4 of the ICTY Statute.

Fourthly, the preparatory works and the draft text of the Rome Statute of the International Criminal Court were viewed as evidence of the status of customary international law on genocide. By assessing that the draft text produced by Preparatory Commission for the ICC constitutes evidence of the opinio iuris of the states, the court demonstrated that the traditional model of "state practice supported by opinio iuris" has not entirely vanished in the vocabulary of the construction of custom by the ICTY.

\footnotetext{
${ }^{80}$ I.C.J., Reservations to the Convention on the Prevention and Punishment of Genocide, Adv. Op., 28 May 1951.
} 
Finally, the court evaluated the "legislation and practice of states, especially their judicial interpretations and decisions”. ${ }^{\mathbf{8 1}}$ For example, the court referred to the French Criminal Code and a decision by the German Constitutional Court in determining that the intent to destroy is as an element of genocide.

However, as in the Furundzija Case, the concepts of state practice and opinio iuris as understood in the traditional construction of customary law were not really articulated. Also, it is surprising, especially in the light of the traditional approach of the construction of customary international law that the court does not draw any distinctions between legally binding documents, actual practice of states, and the so-called soft law documents such as General Assembly resolutions. ${ }^{82}$

In the Hadzihasanovic case (2003), which was concerned with the definition of command responsibility, the Appeals Chamber returned to the traditional construction of custom and stated that "to hold that a principle was part of customary international law, it has to be satisfied that state practice recognised the principle on the basis of supporting opinio iuris" ${ }^{, 3}$ and that "it is the task of a court to interpret the underlying state practice and opinio iuris".

In this connection, it should be noted that the two ad hoc tribunals have adopted somewhat different approaches to the impact of the Rome Statute on their construction of customary law. The ICTY stated in the Furundzija case that "in many areas the Statute may be regarded as indicative of the legal views; i.e., opinio iuris of a great number of states; [...] depending on the matter at issue, the Rome Statute may be taken to restate, reflect or clarify customary rules or crystallise them, whereas in some areas it creates new law or modifies

\footnotetext{
${ }^{81}$ Krstic, supra note 79 , § 541.

${ }^{82}$ The role of General Assembly resolutions in custom formation has not been agreed upon. Akehurst has stated that only those resolutions which claim to be declaratory of existing law, thus lex lata, can be used as authoritative evidence of state practice of customary law by the courts; see M. AKEHURST, "Custom as a Source of International Law”, British Yearbook of International Law, 1974-1975, pp. 1-53, at p. 6. On the other hand, Judge AMMOUN adopted wider approach in his separate opinion in the Barcelona Traction Case by stating that positions taken by delegates of states in international organisations and conferences, with a special emphasis on the United Nations, "naturally form part of state practice”; ICJ, Barcelona Traction, Light and Power Company Limited [Belgium v. Spain)], 5 Feb. 1970, Separate Opinion of Judge Ammoun.

${ }^{83}$ ICTY, Appeals Chamber, Prosecutor v. Hadzihasanovic, IT-01-47-AR72, Decision on Interlocutory Appeal Challenging Jurisdiction in Relation to Command Responsibility, 16 July 2003, § 12.
} 
existing law”. ${ }^{84}$ By contrast, in determining which acts can fall under the category of crimes against humanity, the ICTR in the Akayesu Case referred to the list in Article 7 of the Rome Statute but only after a lengthy deliberation on other sources defining crimes against humanity, for example the Charter of the International Military Tribunal (1945) and the cases of Eichmann (1961), Barbie (1988), and Touvier (1994). ${ }^{85}$

In the 2000 Kupreskic case, concerning the ethnic cleansing of the Bosnian Muslims in the Lasva River Valley, the Trial Chamber of the ICTY discussed whether the attacks on the civilian population were absolutely prohibited under international humanitarian law, and whether the rules prohibiting such acts had become part of customary international law, hence falling under the jurisdiction of the ICTY ${ }^{\mathbf{8 6}}$ The Trial Chamber invoked various sources of evidence for the customary nature of the prohibition.

First, it held that the 1938 Resolution of the Assembly of the League of Nations stating that "the intentional bombing of civilian population is illegal", confirmed by the ICJ in the Legality of the Threat or the Use of Nuclear Weapons Advisory Opinion, is a universally recognised principle.

Secondly, once again, Geneva Conventions were referred to in relation of the demise of the rights of the civilians in a situation where they abuse those rights.

Thirdly, after implying that the prohibition of attacking the civilian population is not an absolute proscription, the court mentioned two general principles: the duty to take reasonable care and the principle of proportionality. According to the court, these principles have been codified in the First Additional Protocol to the Geneva Conventions, and the court concluded that "such provisions [...] are now part of customary international law, not only because they specify and flesh out general pre-existing norms, but also because they do not appear to be contested by any state, including those that have not ratified the Protocol” ${ }^{87}$ The court continued by stating that these principles fall into the area of "elementary considerations of humanity”, and it listed three cases of the ICJ, Corfu Channel Case, Nicaragua Case and

\footnotetext{
${ }^{84}$ Furundzija, supra note 57, § 227; for some commentary, see R. CRYER, "International Criminal Law v. State Sovereignty: Another Round?”, European Journal of International Law, 2005, pp. 979-1000, at p. 992.

${ }^{85}$ Akayesu, supra note 66, §§ 563-577.

${ }^{86}$ Kupreskic, supra note 12, § 521.

${ }^{87}$ Ibid., § 524.
} 
Legality of the Threat or Use of Threat of Nuclear Weapons Advisory Opinion, that illustrate these considerations as general principles of international law. The court confirmed its previous case law to the effect that many provisions of the First Additional Protocol have acquired the status of customary international law.

In relation to the Martens Clause, which the court held to be expressive of customary international law because of the "authoritative view of the ICJ", the court considered that the "principles of humanity" and the "dictates of public conscience”, as these has already been formulated in the 1907 Hague Convention, cannot be seen as independent sources of international law. It is noteworthy that the court nevertheless regarded this denial to a relevant issue to be articulated in the judgment, as if to say that according to some interpretation the principles of humanity and dictates of public conscience could have materialised as independent sources.

Perhaps the most outspokenly progressive idea in Kupreskic judgment is a reformulation of the 'sliding scale' approach to customary international law introduced by Frederick Kirgis in an article of $1987 .^{\mathbf{8 8}}$ Kirgis had suggested that it is possible to disregard either state practice or opinio iuris entirely if there is a very strong evidence of the other one. He had supported this 'sliding scale' theory by a notion of reasonableness and moral considerations: "the more destabilising or morally distasteful the activity [...] the more readily international decision makers will substitute one element for the other, provided that the asserted restrictive rule seems reasonable”. ${ }^{89}$ In relation to the reprisal attacks against civilians, the court pronounced in Kupreskic that:

\footnotetext{
“There does not seem to have emerged recently a body of state practice consistently supporting the proposition that one of the elements of custom, namely usus or diuturnitas ${ }^{\mathbf{9 0}}$ has taken shape. This is however an area where opinio iuris sive necessitates may play a much greater role than usus, as a result of the aforementioned Martens Clause. In the light of the way states and courts have implemented it, this Clause shows that principles of international humanitarian law may emerge through a customary
}

\footnotetext{
${ }^{88}$ F.L. KIRGIS, “Custom on a Sliding Scale”, supra note 11.

${ }^{89}$ Ibid., at p. 149.

${ }^{90}$ Usus = use, experience, skill, advantage, profit, to use, employ, possess, enjoy. Diuturnitas = lasting a long time, of long duration. Results for were found using the Internet version of the Latin Dictionary of the University of Notre Dame: http://archives.nd.edu/latgramm.htm.
} 
process under the pressure of the demands of humanity or the dictates of public conscience, even where state practice is scant or inconsistent". ${ }^{91}$

Significantly, the court considered the importance of the case law in the formation of customary norms. It accepted that in international tribunals the stare decisis principle of common law countries has no direct application, even though the Trial Chamber of the ICTY must follow the decisions of the Appeals Chamber. The court went on to state that "the precedents may constitute evidence of customary rule in that they are indicative of the existence of opinio iuris sive necessitates and international practice on a certain matter, or else they may be indicative of the emergence of a general principle of international law", ${ }^{92}$ Without further analysis, the court said that the decisions of international courts carry much more weight in the formation of customary rules than the decisions of national tribunals, because "international judgments [...] are at least based on the same corpus of law that is applied by international courts”. ${ }^{93}$

This Part has illustrated the wealth of sources used by the ICTY in establishing that a rule of customary international law has emerged. From the case law one can deduct an apparent extension of the variety of the elements in the custom formation, and the significance of the judge in determining where to look for those elements. In addition, the judge has the task of reading in definitions for the customary rules, rules that sometimes have no previous judicial applications.

\section{Conceptual tensions in judicial application and construction of international} customary criminal law

\section{$\underline{\text { A. International customary criminal law and principles of legality }}$}

There has been academic discourse on whether the Charter of the International Military Tribunal codified, and the Nuremberg tribunal applied, existing customary international law or whether they created new, retrospective law, as was discussed in Part I, possibly in breach of the principles of legality. This Part addresses the relationship between the judicial application of the customary criminal norms and the principles of legality in more

\footnotetext{
${ }^{91}$ Kupreskic, supra note 12, § 527.

${ }^{92}$ Ibid., § 540.

${ }^{93}$ Ibid., § 542.
} 
detail and draws illustrations from the case law of the ICTY as well as from some cases decided by national courts. The underlying problem the judge encounters is the conflicting consequences of following the principles of legality, on the one hand, and not allowing impunity, on the other. In other words, the question arises whether the courts should compromise the principles of legality in order to be able to bring perpetrators to justice, or whether they should respect those principles at the cost of justice, and if and how these two aspects should be balanced against one another.

The principles of legality are comprised of the nullum crimen sine lege principle ("no crime without law") and the nulla poena sine lege principle ("no punishment without law"). According to a contemporary commentary, there are four elements to the nullum crimen principle: the concept of written law, the value of legal certainty, the prohibition on analogy, and non-retroactivity. ${ }^{94}$ However, it is noteworthy, that sometimes the concept of the principles of legality is used to refer to merely to the nullum crimen principle (and in a fewer instances only to the nulla poena principle). Likewise, occasionally, the principle nullum crimen is taken to consist of only one or two of the elements, most often of only the nonretroactivity. For the reason of these inconsistencies, the analysis of the case law or the works of scholars is not always unequivocal.

In the Nuremberg trials, the notion of nullum crimen was incorporated into international criminal law from national criminal codes. In the criminal law of the civil law countries the nullum crimen principle, especially its non-retroactivity element, which is purported to proscribe ex post facto laws, is absolute, whereas in the common law countries it has been said to have "the force of an interpretative presumption". ${ }^{95}$ Even though the precedent set by the Nuremberg tribunal on how the application of the customary criminal norms conforms with the nullum crimen principle is somewhat indistinct and unpersuasive, as discussed in above, the subsequent applications of the Nuremberg precedent have reinforced its validity, a process aptly summarised by Professor Bassiouni, saying that "reiteration of the same argument confirms is validity". ${ }^{96}$

\footnotetext{
${ }^{94}$ See S. LAMB, “Nullum Crimen, Nulla Poena Sine Lege in International Criminal Law”, in A. CASSESE, P. GAETA and J.R.W.D. JONES, The Rome Statute of the International Criminal Court: A Commentary, Volume I, Oxford, Oxford University Press, 2002, Chapter 20, at p. 733.

${ }^{95}$ Ibid., at p. 740, note 30.

${ }^{96}$ C.M. BASSIOUNI, Crimes against Humanity in International Criminal Law, Dordrecht, Nijhoff, 1992, pp. 145-146.
} 
The trial of Adolf Eichmann in Israel in 1961 which is as a whole -luckily- more of an exception in its rather arbitrary interpretation of international law, is an example of the court denying the applicability of the principles of legality in order to reach what the court saw was the only possible moral outcome. Court basically stated that the acts Eichmann was accused of had been prohibited under customary international law "since time immemorial" and at the same time denied that the principle of nullum crimen sine lege, nulla poena sine lege had yet developed into a customary rule. ${ }^{97}$

The case law of the International Military Tribunal has been relied on and reasserted for example in the Canadian case Regina v. Finta, where the accused was a former Hungarian general suspected of Nazi war crimes and crimes against humanity. Justice Cory quoted Kelsen by stating that "to punish those who were morally responsible for the international crime of the Second World War may certainly be considered as more important than to comply with the rather relative rule against ex post facto laws, open to so many exceptions”, ${ }^{\mathbf{9}}$ On the reverse, in the ICTY case Erdemovic (1997) the Presiding Judge Cassese in his separate and dissenting opinion stated that "policy-oriented approach in the area of criminal law runs contrary to the fundamental principle nullum crimen sine lege”. ${ }^{99}$ Subsequently, though, in 2006, Professor Cassese first referred to the principle of substantive justice embraced by the Nuremberg tribunal that "whereby any conduct that is socially harmful or causes danger to society should be prohibited and punished, whether or not that conduct had already been criminalised by law at the moment it had been taken”. ${ }^{\mathbf{1 0 0}}$ After a brief analysis contrasting the national and international criminal law, he states that "the need to make international values upholding human dignity (and the legal rules enshrining those values) prevail over diverging national legislation, tips the balance in favour of international law, to the detriment of the accessibility and foreseeability of criminal law”. ${ }^{101}$ These two statements

\footnotetext{
${ }^{97}$ Supreme Court of Israel, A-G Israel v. Eichmann, 29 May 1962, 36 ILR 277. In a later case Schilingo (2005) of Spanish Audienca Nacional, in the absence of codified rules, the court relied on the pre-existing customary international law criminalising certain atrocities as crimes against humanity. It has been argued by many that the decision breached the nullum crimen principle, especially in the light of the structure of Spanish legal system that entails strict principle of legality. See, for instance, C. TOMUSCHAT, "Issues of Universal Jurisdiction in the Scilingo Case”, Journal of International Criminal Justice, 2005, pp. 1074-1081; A. GIL GIL, "The Flaws of the Scilingo judgment”, Journal of International Criminal Justice, 2005, pp. 1082-1091.

${ }^{98}$ Supreme Court of Canada, Regina v. Finta, 24 Mar. 1994, 1 SCR 701.

${ }^{99}$ ICTY, Appeals Chamber, Prosecutor v. Erdemovic, IT-96-22-A, Separate and Dissenting Opinion of Judge Cassese, 7 Oct. 1997, § 11.

${ }^{100}$ A. CASSESE, "Balancing the Prosecution against Crimes against Humanity and Non-Retroactive Criminal Law: The Kolk and Kislyiy v. Estonia Case before the ECHR”, Journal of International Criminal Justice, 2006, pp. 410-418, at pp. 416-417.

${ }^{101}$ Ibid, at p. 417.
} 
illustrate that Professor Cassese, despite rejecting that policy considerations should affect the application of the criminal law, accepts that some considerations, for instance upholding the human dignity, may be taken into account in the decision-making and they should even rebuff the principles of legality. This fluidity also reflects the more general problematic the judge is faced with in evaluating the principles of legality under the nullum crimen principle, such as the value of legal certainty, and not allowing impunity for morally wrongful acts in international criminal tribunals.

A subsequent former President of the ICTY, Professor Meron, has recently taken a conservative view on compliance with the principles of legality in constructing, or creating, customary international law: "in my view the looser, more progressive approach to the analysis of customary international law embraced by dissents -one that would affirmatively engage the criminal tribunal in the development of customary law, rather than simply in its application- cannot be reconciled with the legality principle”. ${ }^{102}$ From this comment can be deduced that Professor Meron rejects the idea that the judges, here presumably main emphasis being on the ICTY, play a role in the evolution of customary norms. However, Meron accepts that "a more relaxed approach to the identification of relevant customary norms may be justified where a norm in question does not concern the substantive scope of the criminal prohibition, or of the defendant's liability, and thus does not directly implicate the nullum crimen principle". ${ }^{103}$ He does not offer any further reasons or analysis on why the method of custom construction should be different in "non-substantive scope of criminal prohibition or defendant's liability" than in the substantive matters, nor explanation on whether it is for the judge himself to determine when “a more relaxed approach" could be resorted to. Interestingly, nearly two decades earlier, much before being elected as a judge to the ICTY and before there was any indication that such tribunal would be established - Professor Meron wrote that "the tribunals have [thus] been guided, and are likely to continue to be guided, by the degree of offensiveness of certain acts to human dignity; the more heinous the act, the more the tribunal will assume that it violates not only a moral principle of humanity but also a positive norm of customary law”. ${ }^{104}$ So, it seems that Meron's experience as a judge in the

\footnotetext{
${ }^{102}$ T. MERON, "Revival of Customary Humanitarian Law”, American Journal of International Law, 2005, pp. $817-834$, at p. 825. ${ }^{103}$ Ibid., at p. 829.

${ }^{104}$ T. MERON, “The Geneva Conventions as Customary Law”, American Journal of International Law, 1987, pp. 348-370, at p. 361.
} 
ICTY, perhaps surprisingly, made him embrace a more restrictive approach on the role of international criminal judge in the development of customary international law.

In relation to the application of customary international law by the international criminal judge and the compliance with the nullum crimen principle, the problem has been the imprecision of some of the customary norms; even though it can be shown that a general prohibition in customary international law has emerged, its scope and substance must be determined by the judges. For example, despite the general recognition that torture can constitute a war crime and a crime against humanity, the court in the Furundzija (1998) case, discussed in more detail above in Part II, was left with the task of determining on the basis of various sources including human rights treaties what the elements of torture are, and if rape could be a form of torture and thus a war crime and a crime against humanity. ${ }^{105}$ Furthermore, the Appeals Chamber of the ICTY stated in the case Delalic (2001), ${ }^{\mathbf{1 0 6}}$ referring to the previous Aleksovski Case (2000), ${ }^{\mathbf{1 0 7}}$ that "the principle of nullum crimen sine lege does not prevent a court from interpreting and clarifying the elements of a particular crime”. ${ }^{\mathbf{1 0 8}}$ Subsequently even more avant-garde approach has been put forward in the joint Milutinovic, Sainovic and Ojdanic Case (2003), where the Appeals Chamber held that the nullum crimen principle prevents the court from creating new law and from interpreting existing law "beyond reasonable limits of clarification" but does not preclude "the progressive development of law by the court". ${ }^{109}$ The court found support for the latter view in the case law of national courts as well as the European Court of Human Rights. Mohamed Shahabuddeen, a current judge in the ICTY, has implicated that as long as the interpretation, or even the expansion, of the elements of the crime are "within the very essence of the original crime even though not corresponding to every detail of it”, the court does not infringe the nullum crimen principle. ${ }^{\mathbf{1 1 0}}$

It has been suggested that the breach of the nullum crimen principle could be justified by the rationale that those who commit the most heinous atrocities should not go unpunished

\footnotetext{
${ }^{105}$ Furundzija, supra note 57, §§ 159-186.

${ }^{106}$ ICTY, Appeals Chamber, Prosecutor v. Delalic, IT-96-21-T, Judgment, 20 Feb. 2001.

${ }^{107}$ ICTY, Appeals Chamber, Prosecutor v. Aleksovski, IT-95-14/1-T, Judgment, 24 Mar. 2000.

${ }^{108}$ Delalic, supra note 106, § 173.

${ }^{109}$ ICTY, Appeals Chamber, Prosecutor v. Milutinovic, Sainovic and Ojdanic, IT-99-37-AR72, Decision on Dragoljub Ojdanic’s Motion Challenging Jurisdiction, 21 May 2003, §§ 37-38.

${ }^{110}$ M. SHAHABUDDEEN, "Does the Principle of Legality Stand in the Way of Progressive Development of Law?”, Journal of International Criminal Justice, 2004, pp. 1007-1017.
} 
even when no clear legal rule has prohibited the acts at the time they were committed. ${ }^{\mathbf{1 1 1}}$ If one adopts the view that the judges may create new law, perhaps a more substantive justification for retroactive application of the principles of law is that "the principle[s] of legality is [...] a principle of justice flowing from natural law doctrine”. ${ }^{112}$ The Nuremberg tribunal accepted that the principle of non-retroactivity is "in general a principle of justice" but it could not be invoked to protect the accused as such, because in relation to atrocities, "it would be unjust if his wrong were allowed to go unpunished”. ${ }^{113}$ From this premise, it could be deduced that the principles of legality -or at least some parts of it- should not be accepted for the purpose of allowing immoral or unjust outcome. However, in contrast to the relaxed approach to the application of the principles of legality endorsed by the IMT, and to lesser extent by the ICTY, it can be presumed that the judges in the ICC are left with much less discretion on this matter, and the Rome Statute unambiguously asserts that "the Court has jurisdiction only with respect to crimes committed after the entry into force of this Statute”.114

\section{B. Applicability of human rights norms directly in international criminal}

\section{proceedings}

Deducing international criminal law that gives rise to individual criminal responsibility directly from treaties that were intended to be applied between the state parties has been thought somewhat troublesome already in the 1940s after the Nuremberg judgment. In relation to the crimes against peace the Nuremberg tribunal stated that any breach of the 1928 Paris Pact, ${ }^{115}$ which created binding obligations on states, was illegal, and furthermore, without explaining the correlation, held that such an illegal act constitutes a crime entailing individual responsibility. ${ }^{116}$ In recent times, mainly in the ICTY, international judges have encountered the issue of direct incorporation of the human rights (treaty or customary) norms to international criminal law, which involves individual criminal responsibility. ${ }^{\mathbf{1 1 7}}$ In other

\footnotetext{
${ }^{111}$ For references, see G. ENDO, “Nullum Crimen Nulla Poena Sine Lege Principle and the ICTY and ICTR”, Revue québécoise de droit international, 2005, pp. 205-219.

${ }^{112}$ S. GARIBIAN, “Crimes against humanity and international legality in legal theory after Nuremberg”, Journal of Genocide Research, 2007, pp. 93-111, at p. 99.

${ }^{113}$ I.M.T., Nuremberg Judgment, 1946, Cmd. 6964, at p. 217.

${ }^{114}$ Rome Statute, Article $11 \S 1$; for further discussion, see H-H. JESCHECK, "The General Principles of International Criminal Law Set Out in Nuremberg, as Mirrored in the ICC Statute”, Journal of International Criminal Justice, 2004, pp. 38-55.

115 General Treaty for the Renunciation of War as an Instrument of National Policy, supra note 22.

${ }^{116}$ For comments, see G. SCHWARZENBERGER, “The Judgment of Nuremberg”, at pp. 346-347.

${ }^{117}$ In my view a too narrow explanation is that "if a human rights treaty or humanitarian law treaty includes a penal provision directed at individual accountability, then obviously such treaty overlaps with international
} 
words, the court has had to determine how do the obligations of the states entailing state responsibility transfer to the culpability of the individuals? One justification, although not its raison d'être, for the application of the human rights norms directly or as evidence of international customary criminal law by the international criminal courts could be that many of the international human rights norms (especially when referring to the so-called 'core crimes') have been implemented into the national legislation of most countries. The national laws implementing international human rights treaties grant rights to the individuals, and the state must not breach these rights, and moreover the state must ensure that no other individual breaches the human rights of another individual. ${ }^{\mathbf{1 1 8}}$

The problem has been further elaborated by the ICTY. For example, in the case Furundzija (1998), the Trial Chamber stated that albeit torture is prohibited under humanitarian law, that area of law does not provide a definition for torture as a war crime. ${ }^{\mathbf{1 1 9}}$ The court referred to a case decided less than a month previously, Delalic (1998), where another Trial Chamber derived a definition for torture, which it said was consistent with customary international norms, directly from human rights law. ${ }^{\mathbf{1 2 0}}$ More precisely, the court in Delalic attained its findings for this definition from various human rights instruments -both legally binding as well as non-binding- both international and regional, for example the Universal Declaration of Human Rights, the European Convention on Human Right, the American Convention on Human Rights and the African Charter on Human and Peoples' Rights. ${ }^{121}$ In considering the instruments focusing just on torture -the Torture Convention, the United Nations General Assembly Declaration on the Protection from Torture, and the InterAmerican Convention to Prevent and Punish Torture- the court concluded that "the definition of torture contained in the Torture Convention includes the definitions contained in both the Declaration on Torture and the Inter-American Convention and thus reflects a consensus which the Trial Chamber considers to be representative of customary international law”. 122

criminal law"; C. DE THAN and E. SHORTS, International Criminal Law and Human Rights, London, Sweet and Maxwell, 2003, at pp. 12-13.

118 See, for example, the decision: E.C.H.R., Osman v. the United Kingdom, 10 July 1998.

${ }^{119}$ Prosecutor v. Furundzija, supra note 57, § 159.

${ }^{120}$ Delalic, supra note 67, 16 Nov. 1998, §§ 452-460.

121 Ibid., §§ 452-458.

122 Ibid., § 459. 
The interpenetration of human rights law, in relation to torture, to international criminal law was further discussed in the case Kunarac (2001). ${ }^{123}$ After reviewing again many human rights instruments and the case law of various legal systems, the court concluded that:

\footnotetext{
"The definition of torture contained in the Torture Convention cannot be regarded as the definition of torture under customary international law which is binding regardless of the context in which it is applied. The definition of the Torture Convention was meant to apply at an inter-state level and was, for that reason, directed at the states' obligations. [...] The definition of torture contained in Article 1 of the Torture Convention can only serve, for present purposes, as an interpretational aid”. 124
}

Furthermore, the Trial Chamber in Kunarac held, challenging the argumentation of Delalic, that "the definition of torture under international humanitarian law does not comprise the same elements as the definition of torture generally applied under human rights law”. ${ }^{\mathbf{2 5}}$

It is interesting to ask what led the court to depart from the previous decisions in this case. The main substantial difference to human rights instruments in the court's interpretation of the elements of torture was that the involvement of a state -the requirement that the offence is carried out by a state official- was perceived by the court as 'peripheral' ${ }^{\mathbf{1 2 6}}$ From these decisions it is possible to perceive a move towards the construction of customary criminal law independently from the impetus of human rights law. ${ }^{127}$ This move "toward the formation of a fully-fledged body of law in this area" ${ }^{128}$ illustrated the impact of the decisions of the international criminal judge on the general body of international law - here, the disintegration of human rights law and international criminal law.

\section{Conclusion}

In international criminal law, the decisions of courts play an increasing role in custom formation despite some academic opposition to the active role of the judge in the development customary international norms. In the judicial decisions, resolutions and statements of non-

\footnotetext{
${ }^{123}$ I.C.T.Y., Prosecutor v. Kunarac, IT-93-23-T \& IT-96-23/1-T, Judgment, 22 Feb. 2001.

${ }^{124}$ Ibid., § 482.

125 Ibid., § 496.

${ }^{126}$ Ibid., § 493.

${ }^{127}$ See, for instance, S.R. RATNER, “The Schizophrenias of International Criminal Law”, Texas International Law Journal, 1998, pp. 237-256.

${ }^{128}$ A. CASSESE, “International Criminal Law”, in M.D. EVANS, International Law, Oxford, Oxford University Press, 2003, Chapter 23, at p. 724.
} 
state institutions are increasingly accepted as evidence of state practice, opinio iuris, or even both, contributing to the custom formation. Moreover, the international criminal judge has the discretion to determine which sources are invoked as evidence of customary norm, and thus, the choices of the judge may influence the general theory of how customary international law forms.

In some cases -for instance, in Tadic-, the ICTY has implied that declarations and even practice of non-state organs, whether international organisations, NGOs, or secessionist movements, could have a direct impact on the formation of customary international law. A question arises, therefore, whether the concept of state practice as an element of custom is becoming outdated, at least in some fields of international law. Moreover, we can ask whether the developments in international criminal law, and more precisely in the interpretation of law by the international criminal tribunals, reflect a completely new source of evidence of international law in which the role of the international judge is vital for determining the substance and definition of a customary norm.

It has been claimed that "continental writers of positivistic allegiance" have been unwilling to admit that the interpretations of law by judges shape and even afford to the development of customary international law. ${ }^{\mathbf{1 2 9}}$ However, especially the UN ad hoc tribunals, mostly the ICTY, have had a large impact on the formation of international criminal norms, just like the Nuremberg tribunal had half a century previously. The ICTY has invoked its own precedents as evidence of emerged customary norms. Thus, the decisions and opinions of the judges are used as a source of evidence of the state of customary international law. The acceptance of the decisions of the international tribunals on the current status of customary international law as an authoritative expression of opinio iuris could induce state practice into the desired direction and thus fundamentally affect the compliance by the states with a new customary norm.

Two conceptual issues, the application of the principles of legality and customary human rights law in international criminal tribunals, are still in the midst of academic as well as practical discourse. Also in relation to these issues uniformity is desired and the discretion of the individual judges should be limited in order to provide for legal certainty and consistent

\footnotetext{
${ }^{129}$ R. KOLB, "Selected Problems in the Theory of Customary International Law", Netherlands International Law Review, 2003, pp. 119-150, at p. 128.
} 
development of international criminal law. International criminal law is moving away from the traditional human rights law as the case law illustrates in relation to the issue of direct applicability of customary human rights law in international criminal law tribunals where individual responsibility, instead of the state responsibility, is at stake. The decisions of the international criminal judge influence not only the future method of formation of customary international law in international criminal law but also its interface to human rights law and the theory of custom formation in general public international law.

The previous sections show that there is a definite need for greater consistency in the formation of customary international norms in the ICTY. Different judges and chambers have, even in the phase of ten years, interpreted, applied and also created customary norms using very diverse approaches and methodology. For the further development of customary criminal law it is necessary to establish a common and consistent system of the custom formation and the role of the judge thereto, not least in order to ensure compliance with the principles of legality, such as the nullum crimen principle. It can be expected that the newly instigated International Criminal Court will provide more detailed techniques on this matter. The applicable law as well as the Rules of Procedure and Evidence and the Elements of Crimes of the ICC were quite firmly defined and adopted by the Assembly of States Parties, unlike in the situation of the ICTY where the Rules of Procedure and Evidence were left for the first judges to determine themselves.

I conclude on a quotation, which not only captures the crux of this paper but also entices for future studies on the nature of modern customary international law: "time has come $[. .$.$] to articulate different types (and elements) of [customary international law] in$ relation to different subject matters and areas”. ${ }^{130}$

\footnotetext{
${ }^{130}$ Ibid.
} 